\title{
Changes in biochemical parameters and mitochondrial factor in blood of amateur athletes under influence of marathon running
}

\author{
Y.D. Vinnichuk ${ }^{1}$, A.O. Polischchuk ${ }^{1}$, Y.V. Goshovska ${ }^{2}$, O.S. Sokolova ${ }^{1}$, V.F. Sagach ${ }^{2}$, \\ S.B. Drozdovska ${ }^{1}$ \\ ${ }^{1}$ National University of Ukraine on Physical Education and Sport, Kyiv; \\ ${ }^{2}$ Bogomoletz Institute of Physiology, NAS of Ukraine, Kyiv; e-mail: vinnichukju@gmail.com
}

\begin{abstract}
Detailed laboratory tests help to evaluate the body condition of athletes who accomplish marathon distance, choose right means of recovery, and thus prevent the development of pathology. The biochemical parameters of blood were described at rest, after finish and after $24 \mathrm{~h}$ of recovery. The opening of mitochondrial permeability transition pores as a possible marker of muscle fatigue was tested as mitochondrial factor release (increased OD of blood serum in UV diapason). Our results showed that biochemical markers that need to be controlled in amateur marathon runners include metabolism regulation indicators - aspartate aminotransferase activity (GOT), total creatine kinase (CKNAK), and their ratio (CK NAK/GOT). The GOT level significantly increased by 1.8 times after the marathon and by 2.4 times after $24 \mathrm{~h}$ of recovery. The level of CK NAK and CK NAK/GOT ratio after 24 h of recovery increased by 11.7 and 4.8 times, respectively. The increased activity of sarcoplasmic GOT and CK NAK enzymes, the CK NAK/GOT ratio can indicate the likelihood of skeletal muscle damage. The mitochondrial factor was not detected in the blood neither in resting-state nor after marathon running. These data support the conclusion made after analysis of the biochemical indexes about the satisfactory energy balance of amateur athletes tested.

Key words: marathon; amateur runners; biochemical homeostasis; mitochondrial permeability transition pore.
\end{abstract}

\section{INTRODUCTION}

One of the main objectives of the sports science is to evaluate the athlete's health and to timely detect the level of their adaptation and pathological changes that can be developed as a result of regular and intensive physical exercise. Therefore, it is necessary to measure markers of metabolic processes that are changed in working muscles and viscera.

For long-distance running and especially the marathon, athletes should possess highly developed aerobic abilities, sustain high energy losses without considerable accumulation of lactate in the blood and withstand such factors as terrain, thermal load, etc [1]. Over the last decades, the number of amateur athletes who accomplish the distances of $5 \mathrm{~km}$ and ultramarathon distances (more than $42 \mathrm{~km}$ ) has considerably risen with a significant increase in the number of women runners and athletes of different age groups [2, 3]. In 2010, Kyiv joined the list of cities that hold their own marathons. 1,626 runners took part in the 9th Wizz Air Kyiv City Marathon in 2018. Thus, the biochemical control of long-distance amateur runners' body condition arouses a fair scientific interest.

Long-distance running may cause muscle overfatigue, irreversible damage of muscle cells and changes in the activity of a number of enzymes due to hypoxia. In case of a very long intense muscular activity, the metabolism of neutral lipids and the synthesis of phospholipids are inhibited. Overfatigue also enhances oxidation processes in cardiac and liver tissues,

(C) Y.D. Vinnichuk, A.O. Polischchuk, Y.V. Goshovska, O.S. Sokolova, V.F. Sagach, S.B. Drozdovska 
increases glycogen phosphorolysis and glucose production. Intensification of glycolysis results in increased concentrations of lactic and pyruvic acids and, consequently, the decrease alkaline reserve of the blood [4]. An important factor is a decrease in the ATP resynthesis rate. The lack of ATP is accompanied by a decrease in calcium transients, calcium overload, and development of muscle contracture as well as disturbed neuro-muscular control as a result of depressed synthesis of neurotransmitters.

Since the effective work of the muscles directly depends on the ATP-synthesizing function of mitochondria, the phenomenon of muscle fatigue should be studied thought the prism of mitochondrial mechanisms. Recent studies have shown that the ability of the mitochondria to generate a membrane potential and to synthesize ATP can be significantly impaired due to the formation of nonselective megachannels between the outer and inner mitochondrial membranes - mitochondrial permeability transition pores (MPTP) that are capable of releasing the inner content of mitochondria, namely, substances with a molecular mass of $1500 \mathrm{Da}$. One of them is cytochrome c, which is well-known trigger of the apoptosis cascade. That is why it is believed that the massive opening of MPTP occurs mainly in pathological conditions such as ischemia-reperfusion and is well-studied in various experimental models of myocardial infarction [5]. Additionally, the opening of MPTP is accompanied by swelling of mitochondria, the loss of cristae structure, the uncoupling of the respiratory chain components and a decrease in the ATP producing capacity of mitochondria. Previously, it has been shown that the MPTP opening might be evaluated not only in vitro in suspension of isolated mitochondria but in situ in isolated organ as well [6]. Outflow solution collected during $1 \mathrm{st}$ min of reperfusion of isolated heart is characterized by the peak of optical density (OD) at 245-250 nm. Pretreatment with an inhibitor of MPTP cyclosporin A greatly decreased the UV absorbance of outflow solutions revealing mitochondrial origin of increased OD
[7]. Thus, the mixture of substances that increase the OD of coronary effluents in UV waves was called mitochondrial factor (MF) [6]. In clinical studies, MF was detected in the blood plasma of patients with heart failure who underwent heart surgery with or without the use of cardioplegic solution [8].

MPTP is involved in the regulation of calcium homeostasis; however, the role of MPTP in the mechanisms of muscle fatigue remains unstudied. It was shown that the induction of the of MPTP decreased the amplitude of functional hyperemia in the skin-skeletal muscles area of the dog's posterior limb probably due to inhibition of the function of the vascular endothelium, and the MF levels were as high as the values of FM obtained after ischemia-reperfusion of the isolated rat heart [9]. Thus, the detection of MF release into the bloodstream may indicate damage of the skeletal muscles induced by fatigue. However, this suggestion needs to be approved in human studies in circumstances of different physical activity.

Troponin I, troponin $\mathrm{T}$, natriuretic peptide (BNP), cardiac isoform of creatine phosphokinase (CK-MB) are usually used for monitoring of pathological conditions of the heart in marathon athletes [10-12]. However, the vast majority of these studies are related to professional athletes. Therefore, the monitoring of biochemical indexes and the development of regulatory ranges for amateur athletes is an urgent task for the medicine of sport. The criteria for admission to marathon distances, the individual approach to the training process, as well as the planning of means of recovery and the pharmacological support of amateur athletes may be based on the results of the preliminary examination. The study of blood plasma in UV for the detection of the MF levels is a fast and budgetary method, which may become an additional test of ischemic damage of cardiac or skeletal muscles of athletes after performing the exercise of different intensiveness and duration.

The purpose of the present study was to evaluate the biochemical homeostatic indexes 
and the release of the MF in the blood of amateur athletes in response to long-term physical activity as marathon running.

\section{METHODS}

The study included 12 non-professional athletes who took part in the 9th Wizz Air Kyiv City Marathon (Kyiv, October 7, 2018, distance $42.195 \mathrm{~km}$ ), aged $33.5 \pm 3.9$ years, with $3.5 \pm 1.6$ years of experience in sports.

Biochemical blood plasma indexes of amateur runners were tested $24 \mathrm{~h}$ before the marathon (at rest), within 1-2 $\mathrm{h}$ after the marathon (immediately changes) and after $24 \mathrm{~h}$ of recovery. The blood samples were taken from the elbow vein in the amount of $5 \mathrm{ml}$. At the time of testing, athletes did not have any complaints, acute diseases or injuries. The athletes confirmed their voluntary consent to participate in the study and signed the "Informational agreement".

Total creatine kinase (CK NAK), aspartate aminotransferase (GOT), alanine aminotransferase (GPT), gamma-glutamyltranspeptidase (g-GT), alpha-amylase, alkaline phosphatase (AP), total protein, urea, creatinine, glucose, total cholesterol, triacylglycerols, serum magnesium, inorganic phosphorus were measured in blood serum using the semiautomatic biochemical analyzer "HYMALYZER 3000" "“Human Ltd.", Germany). The muscular tissue damage index was calculated as a ratio of the CK NAK/GOT.

The mitochondrial factor release into the blood stream due to intensive physical activity was also evaluated. Briefly, blood plasma samples obtained before and 1-2 $\mathrm{h}$ after the marathon were diluted in a distilled water $(10 \mu \mathrm{l}$ of sample and $2.99 \mathrm{ml}$ of $\mathrm{H}_{2} \mathrm{O}$ ) and tested in the ultraviolet region of the spectrum $(\lambda=230-260 \mathrm{~nm})$ in quartz cuvetes of $10 \mathrm{~mm}$ size and sensitivity 1 of spectrophotometer "СФ-46". The increased optical density of the samples at 245-250 nm was considered as a presence of MF as a marker of the MPTP opening.

Statistical processing of the results was carried out using a paired and two-sample $\mathrm{t}$-tests, the difference at $\mathrm{P}<0.05$ was considered significant.

\section{RESULTS AND DISCUSSION}

The analysis of results showed changes in biochemical indexes in blood of amateur athletes when comparing baseline data and data from the day after the marathon (Table). The activities of sarcoplasmic GOT and CK NAK enzymes were increased that indicated a deterioration of metabolic processes both in the cardiac muscle and skeletal muscles [14]. The CK NAK activity is also considered to be an indicator of the local fatigue of the neuromuscular apparatus if the value is above $500 \mathrm{U} \times 1^{-1}$, and the CK NAK/ GOT ratio indicates the likelihood of skeletal muscle damage. A significant increase of this index in our study (Table) points to an increase in muscular tissue damage in amateur marathon runners since the CK NAK/GOT ratio was above 10.0. Other researches show an increased CK NAK activity after physical exercise of various intensity including marathon disciplines [1517]. It is well-known that long-distance running causes muscle damage, but the mechanisms behind this effect are still unclear. It is assumed that in long distances, eccentric actions damage muscle fibers leading to the loss of strength and development of inflammatory processes; metabolic stress can also contribute to the symptoms of muscular tissue damage [18]. The highest CK NAK activity was reported in tennis and football players $24-48 \mathrm{~h}$ after the match that correlates with our findings $[16,17]$.

We observed reduced activity of alpha-amylase in the majority of cases (83.3\%) immediately after marathon and $24 \mathrm{~h}$ of recovery; however, the value was within the normal range so the pancreatic function remained satisfactory. In the same number of cases, increased GOT activity during recovery was observed (Table); the value remained within the normal range indicating a satisfactory metabolic function of the liver [14]. Our data are in agreement with data of others who also showed a lack of hepatic damage and 
restoration of the corresponding biochemical indexes $48 \mathrm{~h}$ after a 12 - to 48 -hour marathon in amateurs [19].

It is known that energy is needed to supply muscular activity, and gluconeogenesis relies on the intensive use of glucogenic amino acids and requires the activation of transaminase (GPT, GOT) protein metabolism pathways. Transaminases are also involved in the intensification of proteolysis with further neutralization of toxic amino acids. The GPT level reflects the intensity of the glucose alanine bypass that ensures the integration of the carbohydrate and protein metabolism and regulates initial metabolic pathways through pyruvic acid and alanine. GOT is the key enzyme of the integration of the cycle of tricarboxylic acids, carbohydrate, lipid and protein metabolisms, and a marker of proton transport in mitochondria. GPT activity increases in physical exercise of anaerobic-aerobic mode, while GOT increases in physical exercise of any intensity [15], which is also observed in our study. Almost in all athletes $(83.3 \%)$ the level of total bilirubin was increased after $24 \mathrm{~h}$ of recovery (by $35.9 \%$ ) and exceeded reference limits, which may be related to the non-effective work of the antioxidant system [20,21]. Other authors, who also indicated an increase in the activities of GOT, alkaline phosphatase and the concentration of total bilirubin in athletes immediately after finishing half-marathon $(21.1 \mathrm{~km})$, explaining it by a slowdown of hepatic blood circulation [22].

The concentration of inorganic phosphorus in athletes' blood serum was at the lower limit of reference values at rest and was reduced after

Biochemical blood plasma parameters in amateur marathon runners $(\mathrm{M} \pm \mathrm{SEM})$

\begin{tabular}{|c|c|c|c|c|}
\hline Index & Baseline & $\begin{array}{c}\text { After } \\
\text { marathon }\end{array}$ & $\begin{array}{l}\text { After } 24 \mathrm{~h} \\
\text { of recovery }\end{array}$ & $\begin{array}{c}\text { Reference } \\
\text { range }\end{array}$ \\
\hline Total protein, $\mathrm{g} \times \mathrm{l}^{-1}$ & $69.4 \pm 1.95$ & $71.98 \pm 4.41$ & $66.9 \pm 1.69$ & $65-80$ \\
\hline Urea, $\mathrm{mmol} \times \mathrm{l}^{-1}$ & $11.03 \pm 1.42$ & $12.87 \pm 2.06$ & $11.3 \pm 2.85$ & $2.0-8.3$ \\
\hline Creatinine, $\mu \mathrm{mol} \times 1^{-1}$ & $105.5 \pm 11.3$ & $141.7 \pm 45.5$ & $109.9 \pm 19.7$ & $53-110$ \\
\hline Total bilirubin, $\mu \mathrm{mol} \times \mathrm{l}^{-1}$ & $16.6 \pm 2.68$ & $17.3 \pm 5.13$ & $20.9 \pm 4.66$ & $8.0-20.5$ \\
\hline Glucose, $\mathrm{mmol} \times \mathrm{l}^{-1}$ & $5.55 \pm 0.58$ & $5.48 \pm 0.61$ & $5.8 \pm 0.44$ & $4.2-6.4$ \\
\hline$\alpha$-Amylase, $\mathrm{U} \times \mathrm{1}^{-1}$ & $158.5 \pm 51.9$ & $150.7 \pm 107,8$ & $143.3 \pm 117.3$ & until 220 \\
\hline Alanine aminotransferase (GPT), $\mathrm{U} \times \mathrm{l}^{-1}$ & $20.5 \pm 5.28$ & $23.48 \pm 5.57$ & $28.4 \pm 7.76$ & until 42 \\
\hline Aspartate aminotransferase (GOT), $\mathrm{U} \times \mathrm{l}^{-1}$ & $29.4 \pm 3.81$ & $53.6 \pm 11,06^{*}$ & $69.2 \pm 20.21 * *$ & until 37 \\
\hline Total creatine kinase (CK NAK), $\mathrm{U} \times \mathrm{l}^{-1}$ & $132.1 \pm 47.90$ & $689.7 \pm 257.7$ & $1543.2 \pm 491.8 * *$ & $60-180$ \\
\hline CK NAK/GOT & $4.5 \pm 1.8$ & $12.3 \pm 8.4 *$ & $21.7 \pm 4.9 * *$ & until 10 \\
\hline$\gamma$-Glutamyltranspeptidase, $\mathrm{U} \times \mathrm{l}^{-1}$ & $21.4 \pm 8.61$ & $21.5 \pm 7.22$ & $22.9 \pm 11.41$ & $11-39$ \\
\hline Alkaline phosphatase, $\mathrm{U} \times \mathrm{l}^{-1}$ & $177.1 \pm 59.5$ & $193.9 \pm 57.2$ & $167.8 \pm 48.7$ & 64-306 \\
\hline Total cholesterol, $\mathrm{mmol} \times \mathrm{l}^{-1}$ & $5.1 \pm 0.96$ & $5.3 \pm 0.75$ & $4.3 \pm 0.72$ & $3.0-6.2$ \\
\hline Triglyceride, $\mathrm{mmol} \times \mathrm{l}^{-1}$ & $1.1 \pm 0.38$ & $1.4 \pm 0.36$ & $0.8 \pm 0.26$ & $0.4-1.86$ \\
\hline Magnesium, $\mathrm{mmol} \times \mathrm{l}^{-1}$ & $1.09 \pm 0.03$ & $1.13 \pm 0.15$ & $1.10 \pm 0.08$ & $0.75-1.0-$ \\
\hline Inorganic phosphorus, $\mathrm{mmol} \times \mathrm{l}^{-1}$ & $0.90 \pm 0.20$ & $0.73 \pm 0.22$ & $0.70 \pm 0.12$ & $1.0-2.0$ \\
\hline
\end{tabular}

$* \mathrm{P}<0.05$ vs baseline

$* * \mathrm{P}<0.05$ vs data after marathon 
finish (the value was lower by $23 \%$ after $24 \mathrm{~h}$ of recovery), which points to the reduction of the energy potential of muscle cells and exhausting of the energy storage. Low content of phosphorus may also point to insufficient body saturation with minerals that are intensively excreted with sweat during marathon [23].

When studying protein metabolism, no significant changes of creatinine level (which is generated in muscles during creatine phosphate metabolism and which ensures muscular contraction energy) were observed in the majority of athletes $(66.7 \%)$, though this parameter exceeded reference levels immediately after exercise in all runners (Table). The restoration of normal creatinine level $24 \mathrm{~h}$ after the marathon points to the equilibrium between the rate of its generation in muscles and the rate of renal excretion [14].

Urea is the end product of protein metabolism which characterizes the function of liver and kidneys and is used as a criterion of the recovery of athletes. In our study, the levels of urea exceeded normal levels in all athletes at baseline. However, it was not changed significantly after marathon and $24 \mathrm{~h}$ of recovery whereas it should not be more than $5.5 \pm 1.0 \mathrm{mmol} \mathrm{l}^{-1}$ the next morning after exercises [14, 22, 24]. Additionally, a slight decrease (by 33.6\%) in the concentration of triacylglycerols after $24 \mathrm{~h}$ of recovery was observed in $66.7 \%$ of cases although the mean group results were within the $1.1 \pm 0.5 \mathrm{mmol} \mathrm{l}^{-1}$, which points to balanced processes of replacement and utilization of lipid energy sources in athletes [14, 24]. A lack of changes in lipid metabolism was also confirmed by the insignificant fluctuations of the total cholesterol concentration in $66.7 \%$ of athletes indicating typical changes caused by the mobilization of free fatty acids and cholesterol during long-term physical exercise. Thus, our results are in agreement with the results of other studies of amateur runners [22]. The concentration of total protein, one of the main plastic substrates, decreased by $11.0 \%$ after a day of recovery in 6 athletes, compared to baseline, but it remained within the normal range. The glucose concentration in athletes' blood serum did not changed significantly and remained in the reference range, which points to the satisfactory general energy balance in athletes' bodies before, immediately after the marathon and $24 \mathrm{~h}$ of recovery.

The activity of $\gamma$-GT enzymes (an indicator of liver and bile-excreting path damage) and alkaline phosphatase (reflects the function of bile-excreting paths and the activity of phosphorus-calcium metabolism) also did not exceed the reference range, which indicates that the function of these elements of the hepatobiliary system is not disrupted. However, individual variances were observed. Thus, the $\gamma$-GT activity after a day of recovery increased, compared to baseline, by $38.7 \%$ in 5 athletes and decreased by $48.5 \%$ in 2 athletes; the activity of alkaline phosphatase increased by $5.8 \%$ in 2 athletes and decreased by $15.8 \%$ in 4 athletes. No correlations between biochemical markers, sports experience and the age of marathon athletes have been established.

The determination of the biochemical parameters helps assess the functional state of the body, choose the right training regime, means of recovery and pharmacological support for every athlete individually.

The optical density of blood samples collected before and after the marathon did not increased at wavelengths of $245-250 \mathrm{~nm}$ (Figure) as in the experiments with ischemia-reperfusion of isolated heart or in blood of heart failure patients [6-8]. This indicates the absence of MF in the blood of amateur athletes in the resting state as well as after a long-term physical activity. However, it should be noticed that the optical density of samples collected after the marathon was increased in every tested athlete at all wavelengths $(\mathrm{P}<0.05)$. This fact requires further study but this may be due to the switch of cells to a more economical mode of ATP usage. As a result, less purine nucleotides metabolites released from the cells into the blood stream.

Thus, the absence of MF in blood plasma of 
amateur athletes is in agreement with conclusion we made after analysis of the biochemical indexes about satisfactory energy balance of tested athletes.

Previously, it has been shown that MF is a mixture of substances that generally consist of the purine nucleotides [7], the products of ATP decomposition. The massive release of these metabolites out the mitochondria occurs due to the disruption of mitochondrial membranes in oxidative stress. The absence of MF in the blood of athletes after marathon indicates that MPTP were in inhibited mode ore there were their no massive opening. On the other hand, one of the known inhibitor of MPTP is nitric oxide (NO) [25], which is produced in sufficient quantities under regular physical trainings in sportsmen [26]. Probably, NO provides the integrity of mitochondrial membranes and the absence of the formation of MPTP due to the intense physical activity in amateur athletes who were tested in our research. Despite these findings, the role of MPTP in the mechanisms of fatigue and adaptation of the organism to intense physical activity requires further study not only of professional or amateur athletes, but also of untrained persons of different age groups, sex and health conditions who are often being recommended to proceed physical training for correction of some health problems.

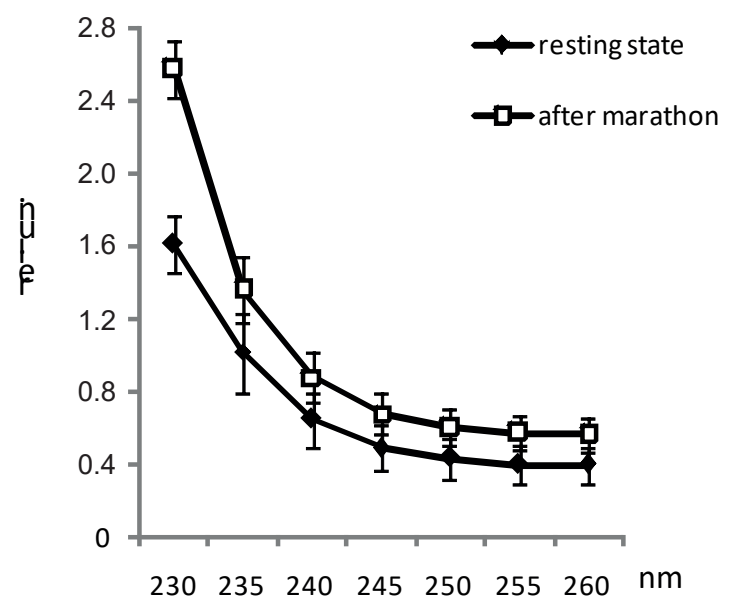

Changes in the optical density of blood plasma samples of amateur athletes before and after marathon running

\section{CONCLUSIONS}

Important biochemical indexes that should be monitored in amateur athletes who run a marathon distance are the indexes of protein metabolism - aspartate aminotransferase activity, total creatine phosphokinase, and their ratio (CK NAK/GOT). The study of the optical density of blood plasma for the presence of the mitochondrial factor may be an additional source of information depicting severe damage of the muscle tissue, the function of mitochondria, and the overall energy balance of the athlete after long-term physical activity.

The authors of this study confirm that the research and publication of the results were not associated with any conflicts regarding commercial or financial relations, relations with organizations and/or individuals who may have been related to the study, and interrelations of coauthors of the article.

\section{Ю.Д. Винничук, А.А. Полищук, \\ Ю.В. Гошовская, О.С. Соколова, В.Ф. Сагач, С.Б. Дроздовская}

ИЗМЕНЕНИЯ БИОХИМИЧЕСКИХ ПОКАЗАТЕЛЕЙ И МИТОХОНДРИАЛЬНОГО ФАКТОРА В КРОВИ СПОРТСМЕНОВ-ЛЮБИТЕЛЕЙ ПОД ВЛИЯНИЕМ МАРАФОНСКОГО БЕГА

Детальное лабораторное исследование позволяет оценить состояние организма спортсменов-любителей, участников марафонских забегов, правильно подобрать средства восстановления, предотвратить развитие патологических состояний. Исследовали биохимические показатели и наличие митохондриального фактора (как возможного маркера переутомления мышц) в крови спортсменов-любителей до, после финиша и через сутки после марафона. Показано, что биохимическими параметрами, которые необходимо контролировать у марафонцев-любителей являются: активность аспартатаминотрансферазы (АсАТ), общей креатинкиназы (КФК) и их соотношение (КФК/ АсАТ). Содержание АсАТ достоверно повысилось после марафонского бега в 1,8 раза, а после 24 ч восстановления - в 2,4 раза. Содержание КФК и соотношение КФК/ AcAT в этот период тоже увеличились в 11,7 и 4,8 раза соответственно. Повышенная активность этих ферментов может свидетельствовать о вероятности повреждения скелетной мышечной ткани. Отсутствие митохондриального фактора в крови спортсменов-любителей согласуется с 
заключением, следующим из анализа биохимических показателей относительно удовлетворительного энергетического баланса у спортсменов после марафона. Ключевые слова: марафон; спортсмены любители; биохимический гомеостаз; митохондриальная пора.

Ю.Д. Вінничук ${ }^{1}$, А.О. Поліщук ${ }^{1}$, Ю.В. Гошовська ${ }^{2}$, О.С. Соколова ${ }^{1}$, В.Ф. Сагач ${ }^{2}$, С.Б. Дроздовська ${ }^{1}$

\section{ЗМІНИ БІОХІМІЧНИХ ПОКАЗНИКІВ I МІТОХОНДРІАЛЬНОГО ФАКТОРА В КРОВІ СПОРТСМЕНІВ-ЛЮБИТЕЛІВ ПІД ВПЛИ- ВОМ МАРАФОНСЬКОГО БІГУ}

Ретельне лабораторне дослідження дає змогу оцінити стан організму спортсменів-любителів, які беруть участь в марафонських забігах, та правильно підібрати засоби відновлення, запобігти розвитку патологічних станів. Досліджували біохімічні показники та наявність мітохондріального фактора (як можливого маркера перевтоми м'язів), в крові спортсменів-любителів в стані спокою, після фінішу, а також через 24 год після марафону. Показано, що біохімічними маркерами, обов'язковими для контролю у марафонців-любителів, $є$ активність аспартатамінотрансферази (АсАТ), загальної креатинкінази (КФК) та їх співвідношення. Вміст АсАТ достовірно підвищився після марафонського бігу в 1,8 раза, а після 24 год відновлення - в 2,4 раза. Вміст КФК і співвідношення КФК/АсАТ в цей період також збільшилися в 11,7 і 4,8 раза відповідно. Підвищена активність цих ферментів може свідчити про ймовірність пошкодження скелетної м'язової тканини. Відсутність мітохондріального фактора в крові спортсменів-любителів в стані спокою та після тривалої фізичної активності узгоджується з висновком, після аналізу біохімічних показників щодо задовільного енергетичного балансу у спортсменів.

Ключові слова: марафон; спортсмени-любителі; біохімічний гомеостаз; мітохондріальна пора.

${ }^{1}$ Національний університет фізичного виховання та спорту Украӥни, Київ;

${ }^{2}$ Інститут фізіології ім. О.О. Богомольия НАН України, Київ.

\section{REFERENCES}

1. Wilmore JH, Costill DL. Sport physiology. K: Olympic literature; 1997. [Russian].

2. Nikolaidis P, Rosemann T, Knechtle B. A Brief Review of Personality in Marathon Runners: The Role of Sex, Age and Performance Level. Sports (Basel). 2018; 6(3):E 99.

3. Knechtle B, Nikolaidis P. Physiology and Pathophysiology in Ultra-Marathon Running. Front Physiol. 2018;9(634):1-33.

4. Klochko LI. Functional fatigue and recovery in conditions of maximum physical training in the marathon running. Pedagogics, psychology, medical-biological problems of physical training and sports. 2007;6:132-5. [Russian].

5. Griffiths EJ, Halestrap AP. Mitochondrial non-specific pores remain closed during cardiac ischaemia, but open upon reperfusion. Biochem J. 1995;307 (Pt1):93-8.

6. Sagach VF, Shymanskaya TV, Nadtochiy SM. Factor released under heart reperfusion may be the marker of opening of the mitochondrial permeability transition pore. Fiziol Zh. 2003;49(4):7-13.

7. Nadtochiy SM, Nauduri D, Shimanskaya TV, Sagach VF, Brookes PS. Purine release: a protective signaling mechanism of the mitochondrial permeability transition pore in ischemia. Fiziol Zh. 2008;54(6):5-14.

8. Sagach VF, Dmitrieva AV, Bubnova JA, Maksimenko VB, Knyshov GV. Using marker of the mitochondrial pore opening in diagnostics of patients with myocardial ischemic lesions. Fiziol Zh. 2009;55(1):12-8.

9. Sagach VF, Boguslavskiy AY, Dmitrieva AV, Nadtochiy $\mathrm{SN}$. The role of NO and mitochondrial permeability transition pore in changes of oxygen consumption in the working skeletal muscle. Fiziol Zh. 2004;50(2):19-26.

10. Frassl W, Kowoll R, Katz N, Speth M, Stangl A, Brechtel L, et al. Cardiac markers (BNP, NT-pro-BNP, Troponin I, Troponin $\mathrm{T}$, in female amateur runners before and up until three days after a marathon. Clin Lab. 2008;54(3-4):81-7.

11. Roth H, Leithauser R, Doppelmayr H, Doppelmayr M, Finkernagel H, von Duvillard S, et al. Cardiospecificity of the 3 rd generation cardiac troponin $\mathrm{T}$ assay during and after a $216 \mathrm{~km}$ ultra-endurance marathon run in Death Valley. Clin Res Cardiol. 2007;96(6):359-64.

12. Zaleski AL, Pescatello LS, Thompson PD, Taylor BA. Protective effect of compression socks in a marathon runner with genetic predisposition to thrombophilia due to Factor V Leiden. Phys Sportsmed. 2005;43(3):324-7.

13. Koriagina YV, Simonova KY. Current problems of physiology long-distance running (analysis of foreign research laboratories for period 2010-2016). Ural Siberia Bull Sports Science. 2016;4(12):20-5. [Russian].

14. Niculin BA, Rodionova II. Biochemical control in sport: scientific method allowance. M.: Sov sport, 2011. [Russian].

15. Ermolaeva EN, Krivihizhina LV. Damage indicators for physical training of different intensity. Fundamental research. 2015;1:1815-21. [Russian].

16. Gomes R, Santos R, Nosaka K, Moreira A, Miyabara E, Aoki M. Muscle damage after a tennis match in young players. Biol Sport. 2014;31(1):27-32.

17. Hagstrom AD, Shorter KA. Creatine kinase, neuromuscular fatigue, and the contact codes of football: A systematic review and meta-analysis of pre- and post-match differences. Eur J Sport Sci. 2018;18(9):1234-44.

18. Lynn A, Garner S, Nelson N, Simper T, Hall A, Ranchordas MK. Effect of bilberry juice on indices of muscle damage and inflammation in runners completing a half-marathon: a randomised, placebo-controlled trial. J Int Soc Sports Nutr. 2018;2;15:22. 
19. Klapcinska B, Waskiewicz Z, Chrapusta S, SadowskaKrępa E, Czuba M, Langfort J. Metabolic responses to a 48-h ultra-marathon run in middle-aged male amateur runners. Eur J Appl Physiol. 2019;113(11):2781-93.

20. Chirkin AA. Metabolism and functional status of athletes aged 12-18 years: Proc. VI Intern. Sceitific Conf. «Health for all». Pinsk, Belarus, 2015;365-8. [Russian].

21. Jastzebski Z, Zychowska M, Jastrebska M, Prusik K, Prusik K, Kortas J, et al. Changes in blood morphology and chosen biochemical parameters in ultra-marathon runners during a $100-\mathrm{km}$ run in relation to the age and speed of runners. Int J Occup Med Environ Health. 2016;29(5):801-14.

22. Lippi G, Salvagno G, Danese E, Tarperi C, La Torre A, Guidi GC, et al. The baseline serum value of $\alpha$-amylase is a significant predictor of distance running performance. Clin Chem Lab Med. 2015 Feb;53(3):469-76.
23. Iordanskaya FA., Cepkova NK. Blood phosphorus: diagnostic and prognostic value in monitoring the functional state of elite athletes. Sports Bcience Bull. 2011;4:30-3. [Russian].

24. Nechvyadovich AI, Nechay EV, Asipovskaya TS. Automated system "Biohim-expert" as a unified method of biochemical assessment of physical and functional preparedness of elite athletes. Minsk: RNPC sport, 2016. [Russian].

25. Shimanskaia TV, Dobrovol'skiı̌ FV, Vavilova GL, Strutinskaia NA, Rudyk EV, Sagach VF. No-dependent modulation of the sensitivity of the mitochondrial permeability transition pore opening under ischemiareperfusion of the isolated heart. Ross Fiziol Zh im I. M. Sechenova. 2009;95(1):28-37.

26. Bohdanovs'ka NV, Kotsiuruba AV, Malikov MV. Nitric oxide synthesis during different stages of competition period in well-trained athletes. Fiziol Zh. 2011;57(4):82-9.

Received 19.08.2019 